$\begin{array}{rr}\text { FIT(PPATOLOGI } & \text { Volume } 11, \text { Nomor 1, Februari } 2015 \\ \text { IN DONESIA } & \text { Halaman } 14-22 \\ \text { ISSN: } 0215-7950 & \text { DOI: } 10.14692 / \text { jfi.13.1.14 }\end{array}$

\title{
Eksplorasi Fusarium Nonpatogen untuk Pengendalian Penyakit Busuk Pangkal pada Bawang Merah
}

\section{Exploration of Nonpathogenic Fusarium for the Control of Basal Rot Disease on Shallot}

\author{
Umi Sallamatul Isniah, Widodo* \\ Institut Pertanian Bogor, Bogor 16680
}

\begin{abstract}
ABSTRAK
Fusarium oxysporum f. sp. cepae sebagai penyebab penyakit busuk pangkal merupakan salah satu kendala dalam produksi bawang. Hasil dari berbagai penelitian menunjukkan adanya potensi $F$. oxysporum nonpatogen dalam pengendalian penyakit ini. Penelitian dilakukan untuk mengeksplorasi dan menguji isolat $F$. oxysporum nonpatogen dari lahan produksi bawang merah dalam mengendalikan penyakit tersebut. Sebanyak 18 dari 21 isolat hasil koleksi tidak menyebabkan gejala penyakit bahkan memacu pertumbuhan bawang merah ketika diinokulasikan ke umbi lapis bawang merah. Dari 18 isolat terpilih tersebut diperoleh 3 isolat $F$. oxysporum nonpatogen yang paling efektif dalam mengendalikan penyakit busuk pangkal, yaitu isolat $\mathrm{P} 13 \mathrm{a}, \mathrm{T} 14 \mathrm{a}$, dan $\mathrm{P} 21 \mathrm{a}$ dengan tingkat efikasi berkisar antara $61.2 \%$ dan $83.3 \%$. Tingkat efikasi tersebut lebih tinggi daripada perlakuan pembanding yang menggunakan fungisida berbahan aktif benomil.
\end{abstract}

Kata kunci: pemacu pertumbuhan, pengendalian hayati, penyakit moler

\begin{abstract}
Fusarium oxysporum f. sp. cepae causing basal rot disease is one of an important constrains in shallot productions. Result from several studies showed that non-pathogenic $F$. oxysporum was very potential to control fusarium basal rot in shallot. This study was conducted to explore non-pathogenic isolates of $F$. oxysporum from shallot fields which might be effective for controlling basal rot disease. Eighteen out of 21 isolates did not cause any disease symptom, they even promoted shallot growth when inoculated onto bulbs. Three out of 18 selected isolates, i.e. P13a, T14a, and P21a were the most effective isolates in controlling the disease in two consecutive experiments with level of efficacy ranges from $61.2 \%$ to $83.3 \%$. This level of efficacy was higher than those of fungicide (benomyl) treatment.
\end{abstract}

Key words: biological control, growth promoting, twisting disease

\section{PENDAHULUAN}

Bawang merah (Allium cepa var. agregatum) merupakan salah satu komoditas hortikultura yang banyak dibutuhkan terutama untuk keperluan bumbu masak. Pada tahun 2013, meskipun secara nasional produksi bawang merah sudah berlebih (Rusono et al. 2013), namun produktivitasnya masih rendah (10.22 ton $\mathrm{ha}^{-1}$ ) dibandingkan dengan potensinya yang masih mungkin dicapai hingga 20 ton ha- (BPS 2014). Secara umum bawang merah cocok ditanam di dataran rendah dan beberapa ada yang dibudidayakan

*Alamat penulis korespondensi: Departemen Proteksi Tanaman, Fakultas Pertanian, Institut Pertanian Bogor, Kampus Darmaga, Jalan Kamper, Bogor 16680

Tel: 0251-8629364, Faks: 0251-8629362, Surel: widodo@ipb.ac.id 
di dataran tinggi. Penyakit busuk pangkal yang disebabkan oleh Fusarium oxysporum f. sp. cepae merupakan salah satu pembatas produksi bawang merah dan bawang bombai (Havey 1999). Gejala yang tampak adalah daun mengering dan meliuk (twisting) dimulai dari atas karena umbinya membusuk. Selain pada pertanaman, penyakit ini juga dapat terjadi pada umbi lapis hasil panen dalam penyimpanan (Widodo et al. 2008). Penyakit ini dilaporkan di Sri Lanka pertama kali antara tahun 1992 dan 1993 dengan gejala utama daun meliuk (Kuruppu 1999), di Indonesia dikenal sebagai "penyakit moler".

Penyakit busuk pangkal yang disebabkan oleh $F$. oxysporum f. sp. cepae juga menjadi kendala dalam produksi bawang putih ( $A$. sativum). Gejala yang ditunjukkan hampir sama, yaitu pengeringan dan pengeritingan daun dimulai dari ujung serta pembusukan umbi atau perakaran (Choiruddin 2010). Inang utama $F$. oxysporum f. sp. cepae ialah bawang bombai (A. sativum var. cepae), namun dapat juga sangat merugikan pada bawang merah, bawang putih, dan bawang daun (Havey 1999).

Pengendalian penyakit yang disebabkan oleh Fusarium yang umum dianjurkan ialah perlakuan tanah secara fisik atau kimiawi dan penggunaan varietas tahan. Rotasi dengan tanaman bukan inang selama 4 tahun atau lebih dapat mengurangi peluang terjadinya infeksi oleh patogen tersebut (Havey 1999). Beberapa varietas resisten sudah diketahui menjadi salah satu alternatif dalam pengendalian penyakit ini di Iran (Esfahani et al. 2012). Secara kimiawi, penggunaan garam natrium fluorida dan natrium metabisulfit dapat menekan perkembangan patogen melalui perlakuan medium tanam (Türkkan dan Erper 2014).

Metode alternatif untuk pengendalian penyakit ini di antaranya ialah pemanfaatan mikrob antagonis Trichoderma harzianum (Santoso et al. 2007; Coskuntuna dan Ozer 2008), cendawan mikoriza arbuskular (Rosyida dan Vita 2008), dan bakteri antagonis Pseudomonas fluorescens (Santoso et al. 2007). Selain cendawan antagonis yang pernah dilaporkan seperti di atas, cendawan
F. oxysporum nonpatogen dilaporkan mampu menekan penyakit busuk pangkal pada bawang bombai (Widodo 2000) dan penyakit layu fusarium pada tanaman lainnya (da Silva dan Bettiol 2005; Abeysinghe 2006; Dhingra et al. 2006). Penelitian ini bertujuan menyeleksi $F$. oxysporum nonpatogen dari lahan produksi bawang merah yang dapat mengendalikan penyakit busuk pangkal pada bawang merah.

\section{BAHAN DAN METODE}

\section{Isolasi Fusarium}

Fusarium diisolasi dari umbi bawang merah yang diambil dari pertanaman bawang merah yang berasal dari Kecamatan Gending, Pajarakan, dan Mayangan di Kabupaten Probolinggo. Umbi bawang merah disterilkan permukaannya menggunakan alkohol $70 \%$, kemudian dipotong-potong dengan ukuran $1 \mathrm{~cm} \times 1 \mathrm{~cm} \times 1 \mathrm{~cm}$ dan diletakkan pada medium selektif untuk Fusarium, yaitu medium pentachloronitrobenzene agar (PCNBA). Isolat yang tumbuh pada medium tersebut dimurnikan dan diremajakan pada medium potato dextrose agar (PDA).

Selain dari umbi, isolasi Fusarium juga diambil dari tanah dengan metode pengenceran. Sebanyak $10 \mathrm{~g}$ tanah disuspensikan dengan $100 \mathrm{~mL}$ air steril kemudian disentrifugasi pada kecepatan 120 rpm selama 20 menit. Setelah itu, pengenceran dilakukan untuk memperoleh suspensi $10^{-2}, 10^{-3}, 10^{-4}$, dan $10^{-5}$. Sebanyak $1 \mathrm{~mL}$ suspensi dari setiap pengenceran dituang ke medium PCNBA. Koloni yang tumbuh dimurnikan dan diremajakan pada medium PDA.

\section{Uji Penapisan Awal}

Uji penapisan awal dilakukan untuk menentukan patogenisitas Fusarium sp. yang diperoleh. Uji ini dilakukan dengan perlakuan perendaman bibit bawang dalam suspensi massa konidium Fusarium selama 30 menit. Sebanyak 21 isolat Fusarium pada medium PDA berumur 1 minggu dikerok pada bagian permukaannya, kemudian koloni Fusarium tersebut diencerkan dengan air steril untuk mendapatkan konsentrasi konidium $10^{6} \mathrm{~mL}^{-1}$. 
Bibit yang telah direndam tersebut kemudian ditanam dalam pot plastik berdiameter $12 \mathrm{~cm}$ dengan medium tanam yang dibeli di toko pertanian, merupakan campuran tanah, pupuk kandang, dan humus (1:1:1).

Pengamatan pengaruh perlakuan isolat Fusarium dilakukan terhadap tingkat perkecambahan umbi, jumlah dan tinggi daun bawang merah. Jika hasilnya lebih baik atau sama dengan kontrol (perlakuan air steril saja) dan tidak menimbulkan gejala penyakit maka diasumsikan isolat tersebut merupakan $F$. oxysporum nonpatogen (Widodo 2000).

Selama pengujian, tanaman bawang merah disiram setiap pagi. Pengamatan dilakukan sampai umur 60 hari setelah tanam (HST) terhadap pertumbuhan tanaman, gejala yang muncul, dan bobot kering umbi per rumpun tanaman. Dari hasil penapisan awal ini dipilih beberapa isolat $F$. oxysporum nonpatogen terbaik dan 1 isolat $F$. oxysporum $\mathrm{f}$. sp. cepae paling virulen yang menunjukkan masa inkubasi tercepat sebagai patogen uji.

\section{Uji Isolat Terpilih terhadap Pertumbuhan Tanaman selain Bawang}

Tanaman mentimun dipilih sebagai tanaman uji untuk penapisan 6 isolat terpilih yang mewakili daerah asal isolat pada percobaan sebelumnya. Pertimbangan penggunaan tanaman ini ialah karena pertumbuhannya yang relatif cepat dan lebih sensitif reaksinya terhadap inokulasi mikrob (Eliza et al. 2007). Dari hasil seleksi ini dipilih 4 isolat $F$. oxysporum nonpatogen yang menunjukkan efek pertumbuhan terbaik pada tanaman mentimun untuk diuji kemampuan penekanannya terhadap $F$. oxysporum f. sp. cepae dalam percobaan berikutnya.

Uji ini dilakukan menggunakan 6 isolat $F$. oxysporum nonpatogen terbaik dan 1 isolat patogen $F$. oxysporum f. sp. cepae. Tujuannya ialah menguji bahwa $F$. oxysporum nonpatogen yang diperoleh juga tidak patogen terhadap tanaman lainnya dan membuktikan bahwa Fusarium yang patogen akan menghambat pertumbuhan tanaman bukan inangnya.

Benih mentimun varietas Venus diperoleh dari toko pertanian. Benih direndam selama satu malam dalam suspensi konidium cendawan dari 6 isolat $F$. oxysporum nonpatogen terpilih dan 1 isolat $F$. oxysporum f. sp. cepae dengan konsentrasi seperti pada percobaan sebelumnya. Sebagai kontrol, benih hanya direndam dalam air steril. Benih yang sudah diberi perlakuan ditanam dalam baki persemaian yang berisi medium seperti pada percobaan penapisan awal.

\section{Penyiapan Klamidospora $F$. oxysporum f. sp. cepae sebagai Inokulum}

Isolat $F$. oxysporum f. sp. cepae yang didapat dari hasil penapisan awal diremajakan dalam medium potato dextrose broth (PDB) dan digoyang dengan kecepatan 120 rpm selama 7 hari. Miselium dan spora yang terbentuk disaring dengan 4 lapis kertas saring Whatman No 1. Pelet yang tertinggal dihancurkan dengan blender dan disuspensikan ke dalam $200 \mathrm{~mL}$ air steril, kemudian dicampur dengan $1 \mathrm{~kg}$ tanah steril (sterilisasi dilakukan 2 kali secara berurutan menggunakan autoklaf). Setelah itu, tanah yang telah dicampur dengan F. oxysporum f. sp. cepae diinkubasi selama 4 minggu untuk mendapatkan klamidospora.

Kerapatan populasi klamidospora dihitung menggunakan metode pengenceran pada medium agar-agar PCNB. Tanah yang mengandung klamidospora disimpan dalam ruangan pada suhu $\pm 17{ }^{\circ} \mathrm{C}$ dan digunakan sebagai sumber inokulum patogen pada uji lanjut.

\section{Uji Keefektifan dalam Mengendalikan F. oxysporum f. sp. cepae}

Bibit bawang merah sehat yang diperoleh dari petani diletakkan di atas kertas tisu yang telah disiram $50 \mathrm{~mL}$ suspensi konidium, masing-masing isolat $F$. oxysporum nonpatogen dengan konsentrasi $10^{3} \mathrm{~mL}^{-1}$. Bibit bawang diletakkan sedemikian rupa sehingga bagian batangnya yang berupa piringan (basal plate) bersentuhan dengan kertas tisu yang sudah dibasahi dengan suspensi konidium $F$. oxysporum nonpatogen dan dibiarkan selama 12 jam. Sebagai perlakuan pembanding digunakan fungisida berbahan aktif benomil dengan konsentrasi $2 \mathrm{~g} \mathrm{~L}^{-1}$ yang diaplikasikan 
seperti pada perlakuan $F$. oxysporum nonpatogen, sedangkan perlakuan air steril menjadi perlakuan kontrol.

Bibit yang telah diberi perlakuan tersebut ditanam pada pot plastik berdiameter $12 \mathrm{~cm}$ yang berisi medium tanam yang telah dicampur dengan klamidospora $F$. oxysporum f. sp. cepae dengan konsentrasi $10^{3}$ klamidospora per gram medium tanam. Isolat $F$. oxysporum nonpatogen yang digunakan dalam percobaan ini ialah isolat T14a, M11a, P13a, dan P21a.

Selama pengujian tanaman bawang merah disiram setiap pagi, dipupuk NPK (15:15:15) sebanyak 2 kali, yaitu pada saat 2 dan 4 minggu setelah tanam (MST) dengan dosis $1 \mathrm{~g} \mathrm{pot}^{-1}$. Peubah yang diamati ialah jumlah daun, tinggi tanaman, hasil panen, dan insidensi penyakit yang disebabkan oleh $F$. oxysporum f. sp. cepae. Uji keefektifan ini dilakukan dalam dua kali percobaan secara berurutan.

\section{Identifikasi Spesies Fusarium}

Identifikasi secara morfologi sampai tingkat spesies terhadap Fusarium, baik yang patogen maupun nonpatogen, dilakukan dengan menggunakan buku kunci Summerell et al. (2003), serta Leslie dan Summerell (2006).

\section{Rancangan Percobaan dan Analisis Data}

Penelitian disusun dalam rancangan acak lengkap dengan 3 ulangan, setiap ulangan terdiri atas 10 pot tanaman. Peubah yang diamati ialah jumlah daun, tinggi tanaman, hasil panen, dan insidensi penyakit. Data yang diperoleh dianalis menggunakan analisis sidik ragam dengan program SAS 9.1.3 pada taraf nyata $95 \%$. Jika hasil analisis menunjukkan beda nyata maka akan dilakukan uji Duncan pada taraf nyata $95 \%$.

\section{HASIL}

\section{Fusarium dan Patogenisitasnya}

Sebanyak 21 isolat Fusarium berhasil diisolasi, baik dari umbi maupun tanah yang diambil di lahan pertanaman dan diuji patogenisitasnya. Isolat yang menyebabkan peubah pertumbuhan, terutama tinggi tanaman, sama atau lebih baik dibandingkan dengan kontrol diasumsikan sebagai isolat yang nonpatogen, sementara yang lebih rendah dan berbeda nyata dengan kontrol diasumsikan sebagai isolat patogen. Sebanyak 21 isolat yang diuji diperoleh 3 isolat yang menyebabkan munculnya gejala kematian tanaman (Gambar 1) dan menurunkan secara nyata tinggi tanaman dibandingkan dengan kontrol, yaitu isolat G21y, P11z dan P13y (Tabel 1). Isolat ini selanjutnya dikategorikan sebagai Fusarium yang patogen dan berdasarkan pada gejala yang ditimbulkan serta identifikasi morfologi isolat tersebut adalah F. oxysporum f. sp. cepae. Isolat lainnya tidak menimbulkan gejala kematian dan tinggi tanamannya tidak berbeda atau bahkan lebih baik dibandingkan dengan kontrol. Dari 18 isolat yang nonpatogen ini ditentukan 7 isolat yang tidak menunjukkan gejala penyakit berupa pembusukan, gejala meliuk, maupun

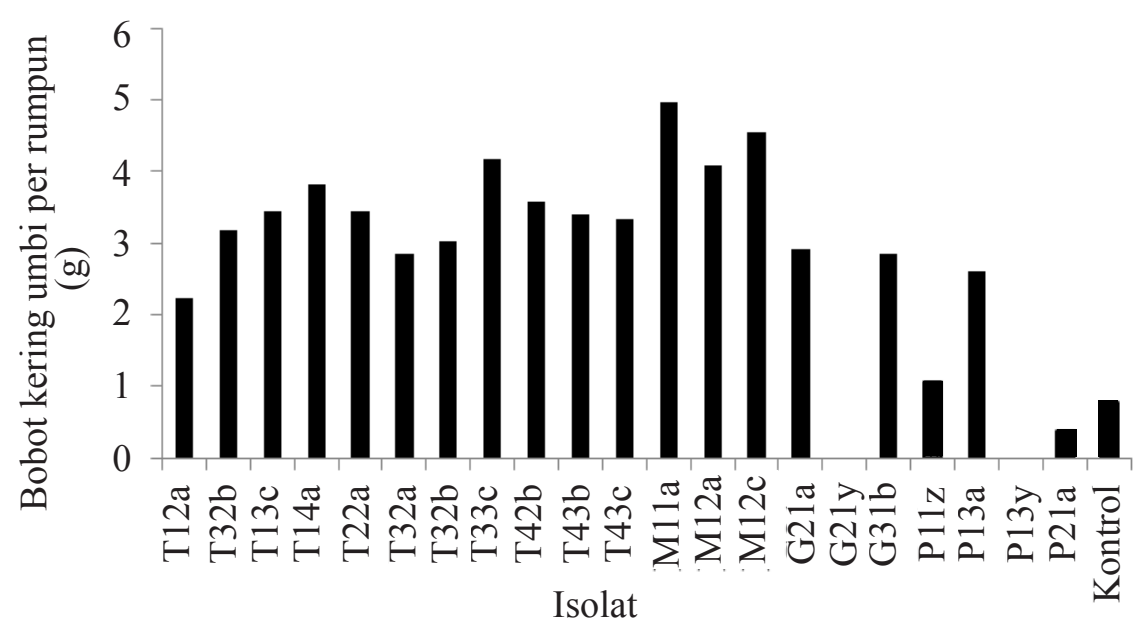

Gambar 1 Bobot kering umbi hasil panen dalam uji patogenisitas isolat Fusarium. 
kekerdilan tanaman, serta tinggi tanamannya berbeda lebih baik $(\geq 3 \mathrm{~cm})$ dibandingkan dengan kontrol (Tabel 1). Selanjutnya isolat tersebut diuji lanjut.

Isolat yang diduga patogen menyebabkan jumlah daun lebih sedikit dibandingkan dengan kontrol, kecuali isolat T43c (Tabel 1). Isolat yang diduga sebagai patogen juga menunjukkan hasil bobot kering umbi yang lebih rendah atau tidak jauh berbeda dengan kontrol. Namun satu isolat, yaitu P21a, yang diduga nonpatogen berdasarkan pada pertumbuhan vegetatif, ternyata bobot umbi keringnya lebih rendah dibandingkan dengan kontrol (Gambar 1).

\section{Fusarium pada Bibit Mentimun}

Identifikasi Fusarium spp. secara morfologi hanya dapat dilakukan sampai tingkat spesies, sedangkan untuk tingkat forma spesiales (f. sp.) harus dilakukan dengan menginokulasikannya pada mentimun. Mentimun digunakan dalam uji ini karena tanaman ini sensitif terhadap inokulasi $F$. oxysporum forma spesiales lainnya selain forma spesiales $F$. oxysporum patogen yang menyerang pada tanaman mentimun (Eliza et al. 2007). Hasil uji 6 isolat terpilih yang bersifat nonpatogen, yaitu T14 a, T42b, M11a, G31b, P13a, dan P21a, pada tanaman mentimun secara umum menunjukkan pertumbuhan tinggi tanaman lebih baik atau tidak terlalu berbeda dengan kontrol, sementara tanaman yang diinokulasi dengan F. oxysporum f. sp. cepae sedikit lebih tertekan dibandingkan dengan kontrol meskipun bobot keringnya tidak berbeda (Tabel 2).

\section{Keefektifan $F$. oxysporum Nonpatogen dalam Mengendalikan $F$. oxysporum f. sp. cepae}

Pada berbagai uji sebelumnya baik pada tanaman bawang merah maupun mentimun dipilih 4 isolat Fusarium, yaitu M11a, P13a, P21a dan T14a, untuk uji keefektifannya dalam pengendalian penyakit busuk pangkal bawang merah. Dalam 2 kali percobaan, terdapat 3 isolat yang secara konsisten mampu menekan perkembangan penyakit busuk batang bawang merah seperti perlakuan dengan fungisida benomil. Isolat tersebut ialah Fusarium T14a, P13a, dan P21a (Gambar 2). Bahkan

Tabel 1 Perlakuan beberapa isolat Fusarium spp. terhadap pertumbuhan tanaman selama 4 minggu

\begin{tabular}{lccc}
\hline Isolat & Tinggi tanaman $(\mathrm{cm})$ & Rata-rata jumlah daun & Keterangan \\
\hline T12a & $28.8 \mathrm{abcd}$ & $12.4 \mathrm{bc}$ & Nonpatogen \\
T13b & $33.6 \mathrm{abc}$ & $15.5 \mathrm{abc}$ & Nonpatogen \\
T13c & $36.6 \mathrm{a}$ & $14.9 \mathrm{abc}$ & Nonpatogen \\
T14a & $35.5 \mathrm{abc}$ & $16.7 \mathrm{abc}$ & Nonpatogen \\
T22a & $37.0 \mathrm{a}$ & $14.0 \mathrm{abc}$ & Nonpatogen \\
T32a & $30.9 \mathrm{abc}$ & $12.7 \mathrm{bc}$ & Nonpatogen \\
T32b & $32.2 \mathrm{abc}$ & $13.4 \mathrm{abc}$ & Nonpatogen \\
T33c & $33.9 \mathrm{abc}$ & $15.8 \mathrm{abc}$ & Nonpatogen \\
T42b & $34.4 \mathrm{abc}$ & $16.3 \mathrm{abc}$ & Nonpatogen \\
T43b & $28.3 \mathrm{abcd}$ & $12.3 \mathrm{bc}$ & Nonpatogen \\
T43c & $25.9 \mathrm{~cd}$ & $10.6 \mathrm{c}$ & Nonpatogen \\
M11a & $33.5 \mathrm{abc}$ & $14.9 \mathrm{abc}$ & Nonpatogen \\
M12a & $35.7 \mathrm{abc}$ & $16.3 \mathrm{abc}$ & Nonpatogen \\
M12c & $36.3 \mathrm{ab}$ & $15.3 \mathrm{abc}$ & Nonpatogen \\
G21a & $26.2 \mathrm{bcd}$ & $12.7 \mathrm{bc}$ & Nonpatogen \\
G21y & $5.1 \mathrm{e}$ & $2.3 \mathrm{~d}$ & Patogen \\
G31b & $38.5 \mathrm{a}$ & $18.2 \mathrm{ab}$ & Nonpatogen \\
P11z & $21.1 \mathrm{~d}$ & $11.1 \mathrm{c}$ & Patogen \\
P13a & $34.9 \mathrm{abc}$ & $19.6 \mathrm{a}$ & Nonpatogen \\
P13y & $5.4 \mathrm{e}$ & $2.9 \mathrm{~d}$ & Patogen \\
P21a & $30.6 \mathrm{abc}$ & $14.2 \mathrm{abc}$ & Nonpatogen \\
Kontrol & $31.6 \mathrm{abc}$ & $12.9 \mathrm{abc}$ & - \\
\hline A & & $\mathrm{abc}$ &
\end{tabular}

Angka yang diikuti dengan huruf yang sama menunjukkan tidak berbeda nyata. 
Tabel 2 Perlakuan Fusarium oxysporum nonpatogen terpilih dan F. oxysporum f. sp. cepae berpengaruh pada pertumbuhan tanaman mentimun

\begin{tabular}{lcc}
\hline Perlakuan & $\begin{array}{c}\text { Rata-rata tinggi tanaman } \\
(\mathrm{cm}) *\end{array}$ & $\begin{array}{c}\text { Bobot kering tanaman } \\
\left(\mathrm{g} \operatorname{tanaman}^{-1}\right)\end{array}$ \\
\hline Kontrol & $11.9 \mathrm{ab}$ & 1.2 \\
M11a & $12.5 \mathrm{ab}$ & 1.4 \\
P21a & $12.1 \mathrm{ab}$ & 1.4 \\
G31b & $12.9 \mathrm{a}$ & 1.2 \\
P13a & $12.6 \mathrm{ab}$ & 1.3 \\
T14a & $12.2 \mathrm{ab}$ & 1.5 \\
T42b & $13.3 \mathrm{a}$ & 1.3 \\
F. oxysporum f. sp. cepae & $10.9 \mathrm{~b}$ & 1.2 \\
\hline
\end{tabular}

P21a, G31b, P13a, T14a, dan T42b merupakan F. oxysporum nonpatogen.

*Angka yang diikuti dengan huruf yang sama menunjukkan tidak berbeda nyata.
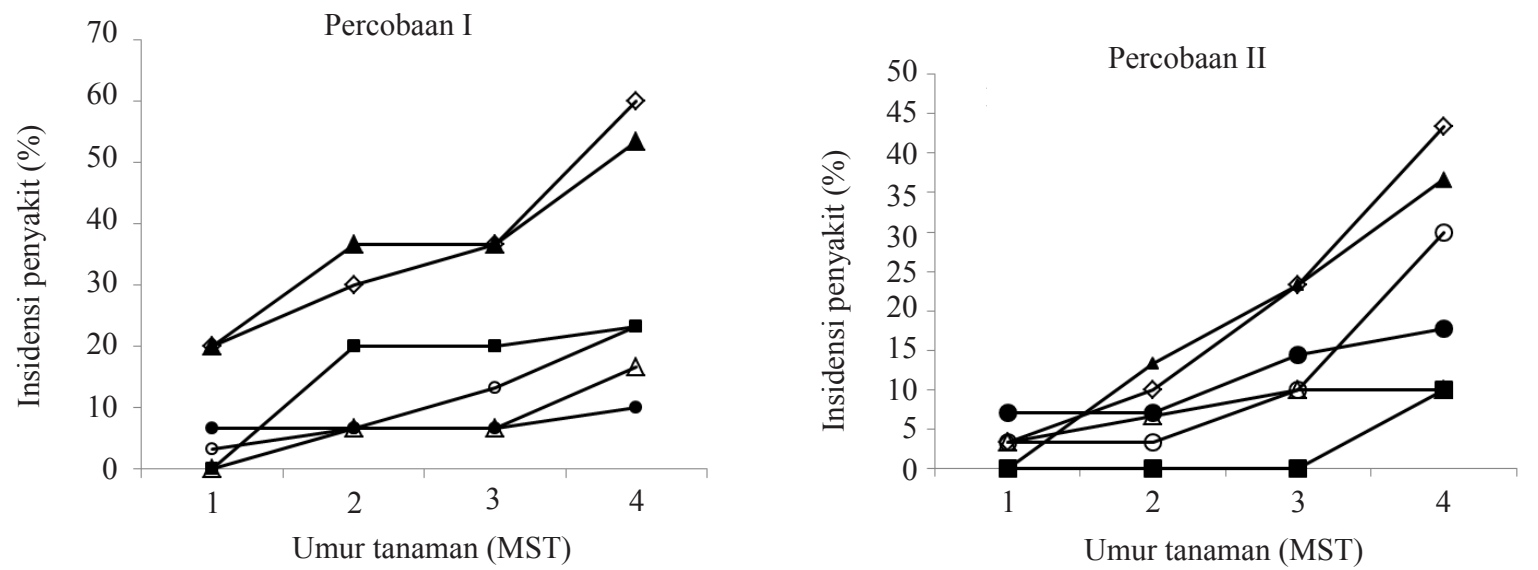

Gambar 2 Perkembangan penyakit busuk pangkal bawang merah dengan perlakuan berbagai isolat Fusarium nonpatogen; $\multimap$, kontrol; _o, benomil; MST, minggu setelah tanam.

pada percobaan ke-2, 3 isolat tersebut lebih baik kemampuannya dibandingkan dengan fungisida benomil. Dari 2 kali percobaan isolat yang diujikan memiliki efikasi berkisar antara $11.1 \%$ dan $83.3 \%$, dan 3 isolat ini menunjukkan konsistensi efikasi di atas 50\% pada pengamatan 4 minggu setelah tanam (Tabel 3). Kecuali isolat M11a, semua isolat yang diuji mampu meningkatkan pertumbuhan vegetatif tanaman pada percobaan pertama dan 2 isolat di antaranya, yaitu T14a dan P13a, berbeda nyata dengan kontrol, sementara pada percobaan ke- 2 semua isolat tidak memberikan perbedaan pengaruh yang nyata (Tabel 4).

Pada ke-2 percobaan yang dilakukan, selain isolat M11a, semua isolat secara umum menunjukkan hasil yang lebih tinggi dibandingkan dengan kontrol, tetapi tidak berbeda nyata. Dari semua isolat yang diuji, secara umum isolat P13a, P21a, dan T14a secara konsisten meningkatkan hasil bobot umbi kering (Tabel 5).

\section{PEMBAHASAN}

Di alam mikroorganisme banyak yang bermanfaat, salah satunya ialah genus Fusarium. Genus ini lebih banyak yang bermanfaat dibandingkan dengan yang merugikan (patogen). Pengendalian hayati yang terjadi secara alami, salah satunya ialah karena adanya peranan Fusarium nonpatogen (Larkin et al. 1996; Dhingra et al 2006; Nel et al. 2006). Beberapa di antara spesies Fusarium nonpatogen tersebut hidup dalam jaringan tanaman (endofit), seperti $F$. solani (Kavroulakis et al. 2007). Beberapa isolat Fusarium nonpatogen juga diperoleh dari 
Tabel 3 Efikasi beberapa isolat Fusarium oxysporum nonpatogen terhadap penyakit busuk pangkal bawang merah pada umur 4 minggu setelah tanam

\begin{tabular}{lccccc}
\hline Perlakuan & \multicolumn{2}{c}{ Percobaan I } & & \multicolumn{2}{c}{ Percobaan II } \\
\cline { 2 - 3 } \cline { 5 - 6 } & $\begin{array}{c}\text { Insidensi penyakit } \\
(\%)\end{array}$ & $\begin{array}{c}\text { Efikasi } \\
(\%)\end{array}$ & $\begin{array}{c}\text { Insidensi penyakit } \\
(\%)\end{array}$ & $\begin{array}{c}\text { Efikasi } \\
(\%)\end{array}$ \\
\hline Kontrol & $60.0 \mathrm{a}$ & 0.0 & & $43.3 \mathrm{a}$ & 0.0 \\
P21a & $23.3 \mathrm{~b}$ & 61.1 & & $10.0 \mathrm{c}$ & 76.9 \\
M11a & $53.3 \mathrm{a}$ & 11.1 & & $36.7 \mathrm{ab}$ & 15.4 \\
T14a & $16.7 \mathrm{~b}$ & 72.2 & & $10.0 \mathrm{c}$ & 76.9 \\
P13a & $10.0 \mathrm{~b}$ & 83.3 & & $17.8 \mathrm{bc}$ & 59.0 \\
Fungisida Benomil & $23.3 \mathrm{~b}$ & 61.1 & & $30.0 \mathrm{abc}$ & 30.8 \\
\hline
\end{tabular}

Angka yang diikuti dengan huruf yang sama menunjukkan tidak berbeda.

Tabel 4 Isolat Fusarium oxysporum nonpatogen pada pertumbuhan vegetatif bawang merah selama 4 minggu setelah tanam

\begin{tabular}{lccccc}
\hline \multirow{2}{*}{ Perlakuan } & \multicolumn{2}{c}{ Percobaan I } & & \multicolumn{2}{c}{ Percobaan II } \\
\cline { 2 - 3 } & $\begin{array}{c}\text { Rata-rata tinggi tanaman } \\
(\mathrm{cm})\end{array}$ & $\begin{array}{c}\text { Rata-rata } \\
\text { jumlah daun }\end{array}$ & $\begin{array}{c}\text { Rata-rata tinggi tanaman } \\
(\mathrm{cm})\end{array}$ & $\begin{array}{c}\text { Rata-rata } \\
\text { jumlah daun }\end{array}$ \\
\hline Kontrol & $13.4 \mathrm{bc}$ & $10.8 \mathrm{bc}$ & $31.9 \mathrm{a}$ & $19.7 \mathrm{a}$ \\
P21a & $18.7 \mathrm{ab}$ & $15.0 \mathrm{ab}$ & $34.4 \mathrm{a}$ & $23.1 \mathrm{a}$ \\
M11a & $8.7 \mathrm{c}$ & $5.6 \mathrm{c}$ & $29.7 \mathrm{a}$ & $17.0 \mathrm{a}$ \\
T14a & $22.4 \mathrm{a}$ & $18.8 \mathrm{a}$ & & $32.7 \mathrm{a}$ & $20.1 \mathrm{a}$ \\
P13a & $24.4 \mathrm{a}$ & $19.8 \mathrm{a}$ & $30.2 \mathrm{a}$ & $17.7 \mathrm{a}$ \\
Benomil & $22.7 \mathrm{a}$ & $17.3 \mathrm{ab}$ & $32.7 \mathrm{a}$ & $20.3 \mathrm{a}$ \\
\hline
\end{tabular}

Angka yang diikuti dengan huruf yang sama menunjukkan tidak berbeda.

Tabel 5 Isolat $F$. oxysporum nonpatogen terhadap bobot kering umbi bawang merah

\begin{tabular}{|c|c|c|}
\hline Perlakuan & $\begin{array}{c}\text { Percobaan I } \\
\begin{array}{c}\text { Bobot kering umbi } \\
\left.\left(\mathrm{g}_{\text {rumpun }}\right)^{-1}\right)\end{array}\end{array}$ & $\begin{array}{c}\text { Percobaan II } \\
\begin{array}{c}\text { Bobot kering umbi } \\
\left(\text { g rumpun }^{-1}\right)\end{array}\end{array}$ \\
\hline Kontrol & $0.48 \mathrm{ab}$ & $4.25 \mathrm{a}$ \\
\hline P21a & $0.72 \mathrm{a}$ & $6.40 \mathrm{a}$ \\
\hline M11a & $0.10 \mathrm{~b}$ & $3.50 \mathrm{~b}$ \\
\hline $\mathrm{T} 14 \mathrm{a}$ & $0.79 \mathrm{a}$ & $4.67 \mathrm{a}$ \\
\hline P13a & $0.75 \mathrm{a}$ & $4.54 \mathrm{a}$ \\
\hline Benomil & $0.77 \mathrm{a}$ & $4.65 \mathrm{a}$ \\
\hline
\end{tabular}

Angka yang diikuti dengan huruf yang sama menunjukkan tidak berbeda.

dalam jaringan umbi bawang merah. Pada penelitian ini, meskipun dari penapisan awal sebagian besar isolat Fusarium yang diperoleh bersifat nonpatogen, namun dalam seleksi lanjut hanya diperoleh 3 isolat yang secara konsisten dapat mengendalikan penyakit pada bawang merah yang disebabkan oleh $F$. oxysporum cepae. Secara umum isolat tersebut dapat mempertahankan dan meningkatkan pertumbuhan serta produksi bawang merah. Beberapa spesies Fusarium yang bersifat nonpatogen, seperti $F$. equiseti, selain dapat mengendalikan penyakit yang disebabkan oleh Fusarium patogen juga diketahui dapat memacu pertumbuhan tanaman (Horinouchi et al. 2011). Salah satu mekanisme pemacu pertumbuhan oleh Fusarium nonpatogen yang mungkin terjadi ialah karena adanya simbosis dengan konsorsium bakteri yang hidup di dalam tanah (Minerdi et al. 2011).

Terkait dengan pengaruhnya terhadap produksi umbi bawang merah dalam penelitian pertama meskipun perlakuan dengan Fusarium nonpatogen masih mampu menekan penyakit, 
tetapi produksi secara keseluruhan jauh lebih rendah dibandingkan dengan perlakuan yang sama pada percobaan ke-2. Hal ini disebabkan bibit yang digunakan dalam penelitian pertama sudah terlalu lama disimpan sehingga daya tumbuhnya sudah berkurang.

Beberapa isolat yang diseleksi dalam penelitian ini, yaitu P13a, P21a, dan T14a, diidentifikasi secara morfologi sebagai $F$. oxysporum. Ketiganya mampu menekan penyakit busuk pangkal fusarium pada bawang merah dengan efikasi di atas 50\% dan lebih tinggi dibandingkan dengan perlakuan fungisida berbahan aktifbenomil. Kemampuan isolat $F$. equiseti yang nonpatogen juga telah ditunjukkan mampu menekan keparahan penyakit layu fusarium pada tanaman tomat dengan efikasi $66.7-88.6 \%$ (Horinouchi et al. 2011). F. oxysporum nonpatogen isolat $\mathrm{CAV}$ 255 dan CAV 241 telah dibuktikan mampu menekan insidensi penyakit layu fusarium pada pisang dengan tingkat efikasi $87.4 \%$ dan 75.0\% (Nel et al. 2006). Dengan demikian, penggunaan isolat $F$. oxysporum nonpatogen tersebut dapat menjadi alternatif pengendalian penyakit tanaman yang ramah lingkungan, khususnya yang disebabkan oleh $F$. oxysporum patogen.

\section{DAFTAR PUSTAKA}

Abeysinghe S. 2006. Biological control of Fusarium oxysporum f. sp. radiceslycopersici, the causal agent of root and stem rot of Cucumis sativus by nonpathogenic Fusarium oxysporum. Ruhuna J Sci. 1:24-31.

[BPS] Badan Pusat Statistik. 2014. Luas Panen, Produksi, dan Produktivitas Bawang Merah 2009-2013.(http://www.bps.go.id/tab_sub/ view.php?kat=3\&tabel=1\&daftar $=1 \&$ id subyek $=55 \&$ notab $=61$ [diunduh 29 Okt 2014].

Choiruddin M R. 2010. Virulensi dan keanekaragaman genetika Fusarium oxysporum f. sp. cepae penyebab busuk pangkal pada bawang putih [skripsi] Surakarta (ID): Universitas Sebelas Maret.
Coskuntuna A, Ozer N. 2008. Biological control of onion basal rot disease using Trichoderma harzianum and induction of antifungal compounds in onion set following seed treatment. Crop Prot. 27:330-336. DOI: http://dx.doi. org/10.1016/j.cropro.2007.06.002.

da Silva JC, Bettiol W. 2005. Potential of non-pathogenic Fusarium oxysporum isolates for control of Fusarium wilt of tomato. Fitopatol Bras. 30:409-412. DOI: http://dx.doi.org/10.1590/S010041582005000400012.

Dhingra OD, Coelho-Netto RA, Rodrigues FA, Silva Jr GJ, Maia CB. 2006. Selection of endemic nonpathogenic endophytic Fusarium oxysporum from bean roots and rhizosphere competent Xuorescent Pseudomonas species to suppress Fusarium-yellow of beans. Biol Control. 39:75-86. DOI: http://dx.doi. org/10.1016/j.biocontrol.2006.04.006.

Eliza, Munif A, Djatnika I, Widodo. 2007. Karakter fisiologis dan peranan antibiosis bakteri perakaran Gramninae terhadap Fusarium dan pemacu pertumbuhan tanaman pisang. J Hort. 17(2):150-160.

Esfahani MN, Hossaini M, AShrafi N. 2012. Screening of Iranian onion seed sets genotypes for resistance to Fusarium oxysporum f. sp. cepae. Intl J Farm Alli Sci. 1(1):9-15.

Havey MJ. 1999. Fusarium basal plate rot. Di dalam: Schwartz HF, Mohan SK, editor. Compendium of Onion and Garlic Diseases. St Paul-Minnesota (US): APS Pr. hlm 10-11.

Horinouchi H, Watanabe H, Taguchi Y, Muslim A, Hyakumachi M. 2011. Biological control of Fusarium wilt of tomato with Fusarium equiseti GF191 in both rockwool and soil systems. Bio Control. 56:915-923. DOI: http://dx.doi. org/10.1007/s10526-011-9369-3.

Kavroulakis N, Ntougias S, Zervakis GI, Ehaliotis C, Harampalidis K, Papadopoulou KK. 2007. Role of ethylene in the protection of tomato plants against 
soil-borne fungal pathogens conferred by an endophytic Fusarium solani strain. J Exp Bot. 58(14):3853-3864. DOI: http:// dx.doi.org/10.1093/jxb/erm230.

Kuruppu PU. 1999. First report of Fusarium oxysporum causing a leaf twisting disease on Allium cepa var. ascalonicum in Sri Lanka. Plant Dis. 83(7):695. DOI: http:// dx.doi.org/10.1094/PDIS.1999.83.7.695C.

Larkin RP, Hopkins DL, Martin FN. 1996. Suppression of fusarium wilt of water melon by nonpathogenic Fusarium oxysporum and other microorganisms. Phytopathology. 86:812-819. DOI: http:// dx.doi.org/10.1094/Phyto-86-812.

Leslie JF, Summerell BA. 2006. The Fusarium Laboratory Manual. Iowa (US): Blackwell Publishing Ltd. DOI: http://dx.doi. org/10.1002/9780470278376.

Minerdi D, Bossi S, Maffei ME, Gullino ML, Garibaldi A. 2011. Fusarium oxysporum and its bacterial consortium promote lettuce growth and expansion A5 gene expression through microbial volatile organic compound (MVOC) emission. FEMS Microbiol Ecol. 76:342-351. DOI:http://dx.doi.org/10.1111/j.15746941.2011.01051.x.

Nel B, Steinberg C, Labuschagne N, Viljoen A. 2006. The potential of nonpathogenic Fusarium oxysporum and other biological control microorganisms for suppressing fusarium wilt of banana. Plant Pathol. 55:2177-223. DOI: http://dx.doi. org/10.1111/j.1365-3059.2006.01344.x.

Rosyida, Taufika V. 2008. Pengendalian penyakit moler bawang merah dengan inokulasi jamur mikoriza arbuskula di lahan pasir pantai [tesis] Yogyakarta (ID): Universitas Gadjah Mada.

Rusono N, Suanri A, Candradijaya A, Muharam A, Martino I, Tejaningsih, Hadi PU, Susilowati SH, Maulana M. 2013. Rencana Pembangunan Jangka Menengah Nasional (RPJMN) Bidang Pangan dan Pertanian 2015-2019. Jakarta (ID): Direktorat Pangan dan Pertanian, Bappenas.

Santoso SE, Soesanto L, Haryanto TAD. 2007. Penekanan hayati penyakit moler pada bawang merah dengan Trichoderma harzianum, Trichoderma koningii, dan Pseudomonas fluorescens P60. J HPT Trop. 7(1):53-61.

Summerell BA, Salleh B, Leslie JF. 2003. Autilitarian approach to Fusarium identification. Plant Dis. 87(2):117128. DOI: http://dx.doi.org/10.1094/ PDIS.2003.87.2.129.

Türkkan M, Erper I. 2014. Evaluation of antifungal activity of sodium salts against onion basal rot caused by Fusarium oxysporum f. sp. cepae. Plant Protect Sci. 50(1):19-25.

Widodo. 2000. Studies on the biological control of fusarium basal rot of onion caused by Fusarium oxysporum f. sp. cepae [disertasi]. Sapporo (JP): Hokkaido Univ.

Widodo, N Kondo, K Kobayashi, A Ogoshi. 2008. Vegetative compatibility groups within Fusarium oxysporum f. sp. cepae in Hokkaido Japan. Microbiol Indones. 21(1):39-43. DOI: http://dx.doi. org/10.5454/mi.2.1.8. 